\title{
Deep-sea macrofauna exposed to a simulated sedimentation event in the abyssal NE Atlantic: in situ pulse-chase experiments using ${ }^{13}$ C-labelled phytodetritus
}

\author{
N. Aberle ${ }^{1,2, *}$, U. Witte ${ }^{1}$ \\ ${ }^{1}$ Max Planck Institute for Marine Microbiology, Celsiusstr. 1, 28359 Bremen, Germany \\ ${ }^{2}$ Present address: Max Planck Institute for Limnology, August-Thienemann-Str. 2, 24306 Plön, Germany
}

\begin{abstract}
Tracer experiments with ${ }^{13} \mathrm{C}$-labelled diatoms Thalassiosira rotula (Bacillariophycea, $98 \%{ }^{13} \mathrm{C}$-labelled) were conducted at the Porcupine Abyssal Plain (PAP) in the NE Atlantic (BENGAL Station; $48^{\circ} 50^{\prime} \mathrm{N}, 16^{\circ} 30^{\prime} \mathrm{W}, 4850 \mathrm{~m}$ depth) during May/June 2000. In situ enrichment experiments were carried out using deep-sea benthic chamber landers: within the chambers a spring bloom was simulated and the fate of this food-pulse within the abyssal macrobenthic community was followed. In focus was the role of different macrofauna taxa and their vertical distribution within the sediment column in consuming and reworking the freshly deposited material. T. rotula is one of the most abundant pelagic diatoms in the NE Atlantic and therefore $0.2 \mathrm{~g}$ of freeze dried T. rotula, equivalent to $1 \mathrm{~g}$ algal $\mathrm{C} \mathrm{m}^{-2} \mathrm{yr}^{-1}$, was injected into each incubation chamber. Three different incubation times of 2.5, 8 and $23 \mathrm{~d}$ were chosen in order to follow the uptake of ${ }^{13} \mathrm{C}$-labelled phytodetritus by macrofauna. After only $2.5 \mathrm{~d}, 77 \%$ of all macrofauna organisms showed tracer uptake. After $23 \mathrm{~d}$ the highest degree of enrichment was measured and $95 \%$ of the individuals had taken up ${ }^{13} \mathrm{C}$ from the introduced algal material. In addition to that a downward transport of organic matter was observed, even though the mixing was not very intense. The initial processing of carbon was dominated by polychaetes that made up a percentage of $52 \%$ of total macrofauna. In general macrofauna organisms that lived close to the sediment surface had higher access to the simulated food-pulse, confirming the hypothesis that individuals close to the sediment surface have the strongest impact on the decomposition of phytodetritus. In our study we observed only modest vertical entrainment of ${ }^{13} \mathrm{C}$-tracers into the sediment. With regard to contradictory results from former ${ }^{13} \mathrm{C}$-enrichment experiments in bathyal regions, compared to results from our study site in the abyssal plain, we thus propose pronounced differences in feeding strategies between macrofauna communities from continental margins and abyssal plains.
\end{abstract}

KEY WORDS: Deep-sea $\cdot$ Pulse-chase experiment $\cdot \delta^{13} \mathrm{C} \cdot$ Benthic carbon remineralisation Macrofauna $\cdot$ Porcupine Abyssal Plain

\section{INTRODUCTION}

Sedimentation of particulate organic matter (POM) produced in the overlying water column by primary production in the euphotic zone is considered to be the main energy source for deep-sea organisms (e.g. Gooday 1988, Gooday \& Turley 1990, Pfannkuche 1993). Large seasonal fluctuations in the deposition of particulate material have been detected in several studies either by using sediment traps (Deuser et al. 1981, Honjo 1982, Lohrenz et al. 1992) or by time-lapse cameras (Billet et al. 1983, Lampitt 1985, Rice et al. 1986, Thiel et al. 1989). During the last $20 \mathrm{yr}$ of deep-sea research, a direct coupling between the activity of benthic fauna and pulse-like sedimentational events has become clear (Gooday 1988, Graf 1989, Pfannkuche 1993). 
Benthic deep-sea communities, especially meio- and macrofaunal species, are described as highly diverse and abundant (Gooday 1986, Gage \& Tyler 1991, Cosson 1997). Within the strongly food-limited abyssal environment, the rapid functional response of benthic organisms to seasonal or episodical energy pulses is striking (Lochte \& Turley 1988, Tyler et al. 1990, Gooday et al. 1993). Foraminifera, for example, show an increase in activity as soon as the sedimentational event reaches the sea floor (Linke et al. 1995), and sponges show a reproductive cycle triggered by vertical fluxes (Witte 1996). In addition to that, infauna can play a major role in reworking the arriving organic material by incorporation, redistribution and vertical mixing within the sediment column, also in the deepsea. At the continental slope of Cape Hatteras $(850 \mathrm{~m})$ a rapid (hours to days) processing and downward mixing of freshly deposited material by macrofauna organisms was detected (Blair et al. 1996, Levin et al. 1997). Similar patterns have been observed in the bathyal regions of the Norwegian Sognefjord at $1265 \mathrm{~m}$ depth where a rapid downward mixing of organic matter has been reported (Witte et al. 2003, this issue). However, not much is known about the fate of fresh algal carbon in abyssal sediments and its pathways through the benthic food-web, and the feeding ecology of most abyssal macrofauna is still poorly understood.

The majority of macrofaunal organisms are considered to be deposit-feeders (surface- or subsurface depositfeeders) or generalists. Carnivore predators, scavengers or suspension feeders are present but not very abundant (Gage \& Tyler 1991). However, a very detailed knowledge about the response time of macrofauna organisms and their accessibility to freshly settled material has still not been established. Until now only few studies have been conducted that throw light on this trophic aspect. Nowell et al. (1984), for example, showed that some Spionids (Polychaeta) were able to change their feeding type from suspension to deposit-feeding in the case of changing food supply. Former studies revealed food selectivity by macrofauna taxa, and showed that deepsea isopods and peracarids prey in general not only on detritus but on living prey such as small crustaceans and foraminiferans as well (Svavarson et al. 1993, Cartes et al. 2001). In addition to that the vertical distribution of organisms within the sediment column may play an important role for the export of organic material. It is discussed as a feeding strategy of, for example, polychaetes, which collect food from surface sediments and store it beneath the surface layer out of reach of competitors (Jumars et al. 1990).

Traditional food-web analysis such as examining gut contents or conducting field and laboratory experiments in order to investigate feeding habits of deepsea organisms is restricted due to limited accessibility as well as the technical and financial efforts required for deep-sea studies. But the establishment of stable isotope techniques (Fry \& Sherr 1986, Peterson \& Fry 1987) has created new opportunities for examining benthic trophic interactions.

This study is part of the BIGSET(II)-programme that investigates the response of an abyssal community to a sedimentation event and focuses on the response of macrofauna to such a highly seasonal food-pulse. In order to investigate trophic relationships within the benthic community, we simulated a food-pulse by injecting ${ }^{13} \mathrm{C}$-labelled diatoms into lander chambers. The uptake of ${ }^{13} \mathrm{C}$-labelled algal material by macrofauna was investigated from sediment samples after incubation times of 2.5, 8 and $23 \mathrm{~d}$. The experimental site (BENGAL Station) lies at $4850 \mathrm{~m}$ water depth within the Porcupine Abyssal Plain (PAP) in the NE Atlantic, and was chosen because it is a well studied deep-sea region characterized by a strong seasonal flux of POM, and because it is considered to be nearly unaffected by the continental slope or advective processes (Billet et al. 1983).

\section{MATERIALS AND METHODS}

During cruise no. 260 of the RV 'Poseidon' (Pfannkuche \& Utecht 2001), pulse-chase experiments were carried out at BENGAL Station $\left(48^{\circ} 50^{\prime} \mathrm{N}, 16^{\circ} 30^{\prime} \mathrm{W}\right)$ in the middle of the PAP (ca. $4850 \mathrm{~m}$ depth), approx. $270 \mathrm{~km}$ southwest of Ireland in May/June 2000 (Fig. 1).

This area was sampled previously between 1989 and 1994 during several projects (Rice et al. 1991, 1994) and

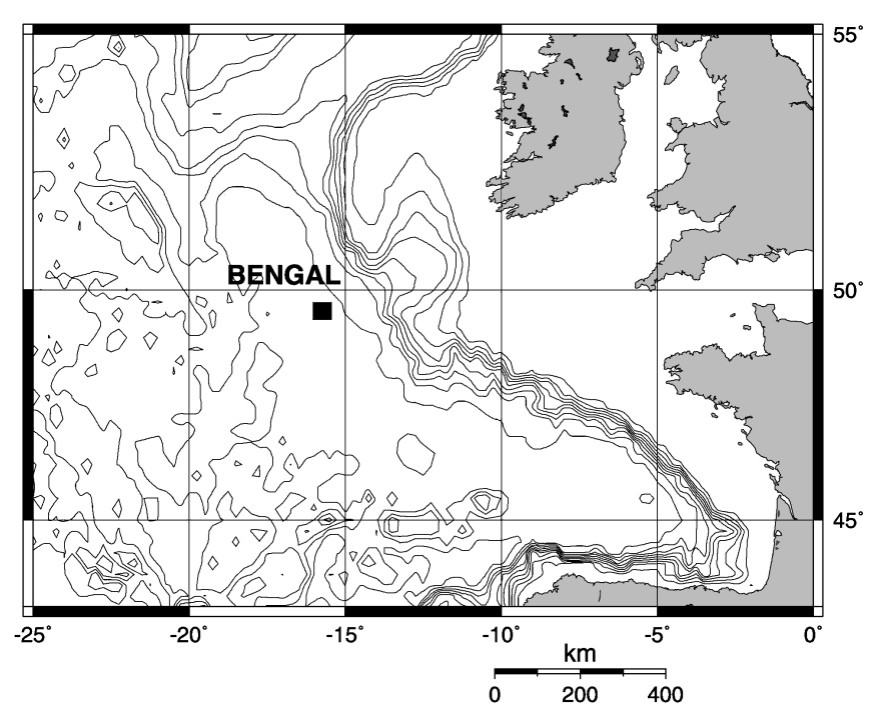

Fig. 1. Location of BENGAL Station at the Porcupine Abyssal Plain (PAP) 
in addition by the EU-funded BENGAL-project from 1996 to 1998 (Billett \& Rice 2001). It is a relatively flat abyssal plain, remote from both the continental slope to the east and the mid-ocean ridge to the west, and thus is largely unaffected by slope processes (Billett et al. 1983). PAP is characterized by a strong vertical flux of POM that lies between 0.8 (Newton et al. 1994) and $1.0 \mathrm{~g} \mathrm{C} \mathrm{m}^{-2}$ $\mathrm{yr}^{-1}$ (Honjo \& Manganini 1993), and a primary production of ca. $200 \mathrm{~g} \mathrm{C} \mathrm{m}^{-2} \mathrm{yr}^{-1}$ (Gooday 1996). The sediment at the site consists of calcareous ooze with a median grain size of 8 to $8.6 \mu \mathrm{m}$ and with a sedimentation rate of $\sim 3.5 \mathrm{~cm} \mathrm{kyr}^{-1}$ (Rice et al. 1991).

The centric diatom Thalassiosira rotula (Bacilariophycea, Biddulphiales) was cultured under laboratory conditions in artificial seawater amended with f/2 medium (Guillard \& Ryther 1962) containing $\mathrm{NaH}^{13} \mathrm{CO}_{3}$ (99 atom\%) (Chemotrade). The algae were cultivated in 101 plastic flasks (Nalgene) under a permanent light regime. After $14 \mathrm{~d}$ each culture was harvested by sieving over a $30 \mu \mathrm{m}$ mesh, freeze-drying and storing in vacuo. The mean $\mathrm{C}: \mathrm{N}$ ratio of the ${ }^{13} \mathrm{C}$-labelled diatoms was 13 , with a ${ }^{13} \mathrm{C}$-content of 98 atom\%. In situ pulsechase experiments were conducted by using benthic chamber lander systems from the Institute of Marine Geosciences (GEOMAR) in Kiel. A detailed description of the lander systems is given by Witte \& Pfannkuche (2000). Each lander was equipped with 3 benthic chambers $\left(0.04 \mathrm{~m}^{2} ; 20 \times 20 \mathrm{~cm}\right)$ and in order to simulate the sedimentation of an early spring bloom, $0.2 \mathrm{~g}$ of freeze-dried ${ }^{13} \mathrm{C}$-labelled $T$. rotula, equivalent to $1 \mathrm{~g} \mathrm{C}$ $\mathrm{m}^{-2} \mathrm{yr}^{-1}$, was inserted into each chamber. The insertion started $1 \mathrm{~h}$ after the landers had settled on the deepsea floor using a special insertion device. Algae were distributed by a stirrer within the chamber in order to guarantee a homogeneous sedimentation of the induced material. The stirring was not strong enough to resuspend sediments but sufficient to achieve a relatively uniform distribution of algae. Incubation times were $2.5,8$ and $23 \mathrm{~d}$. At the end of each incubation period the sediment chambers were closed in situ and the lander systems recalled to the surface. The sediments were sectioned vertically at 0 to 1,1 to 2,2 to 3 , 3 to 5 , and 5 to $10 \mathrm{~cm}$ intervals. Afterwards the sediment layers were sieved through a $250 \mu \mathrm{m}$ mesh and preserved by freezing at $-20^{\circ} \mathrm{C}$. In addition, cores from a multiple corer (Barnett et al. 1984) were taken in order to obtain macrofauna material for the analysis of background ${ }^{13} \mathrm{C}$-signatures. The cores were processed in the same way as the sediments from the benthic chambers. A detailed list of chamber lander and multiple corer (MUC) deployments, and therefore the overall number of samples obtained, is given in Table 1. The samples used to calculate mean macrofauna abundance and biomass data are obtained from chamber lander and MUC deployments; prior to the pooling of samples, both data sets were treated separately but no

Table 1. List of chamber-lander and multiple corer (MUC) deployments during Poseidon cruise no. 260 (4 May to 23 June 2000)

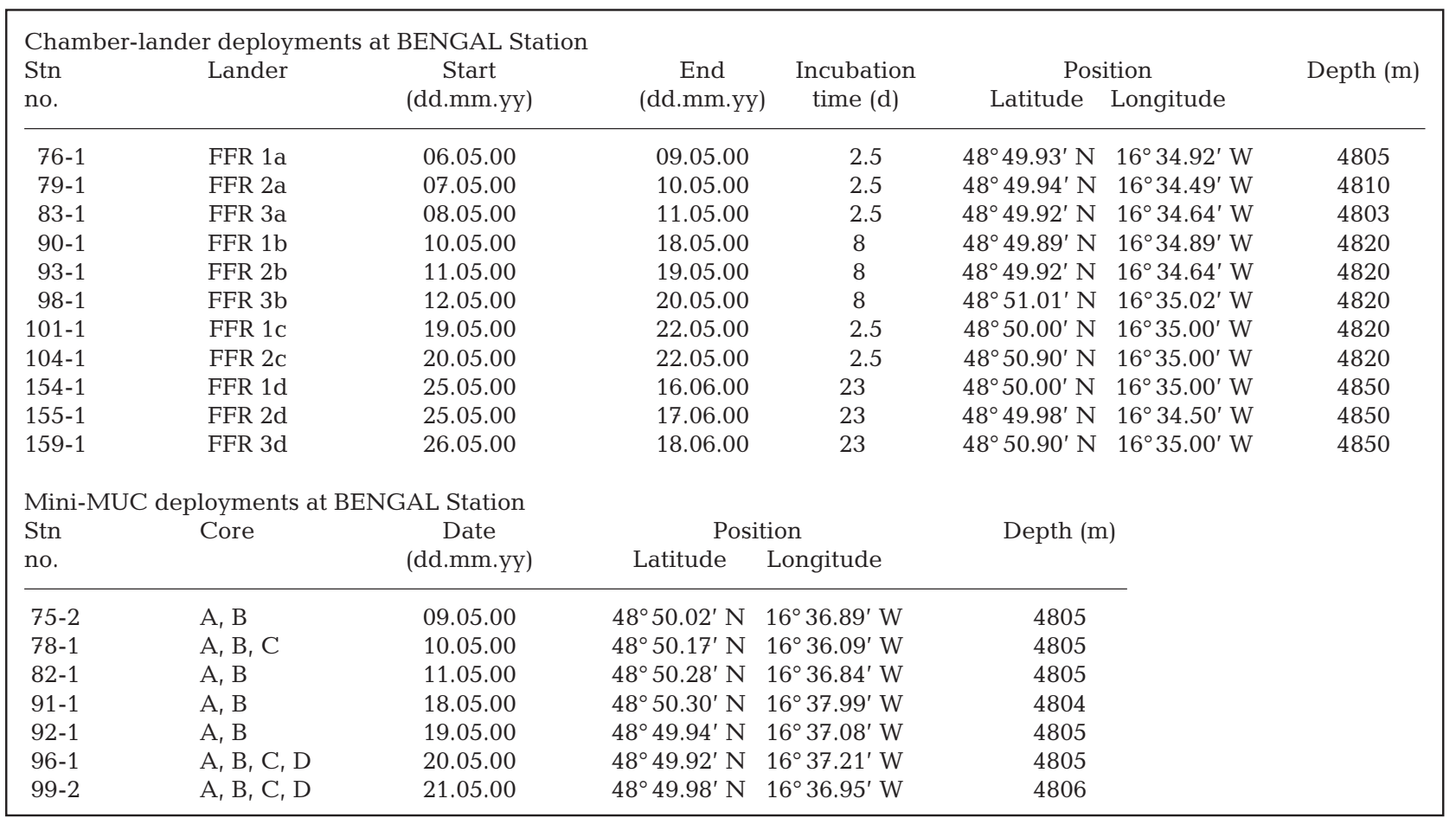


large differences occurred in correlation with sampling technique. The standard deviations (SD) are indicated $( \pm)$. The stations, for each of the different chamber lander- and MUC deployments, were in close proximity to each other and therefore assumed to be comparable; an absolute homogeneity with total exclusion of patchiness could not be guaranteed. In the laboratory all samples were thawed in a cold room at $8^{\circ} \mathrm{C}$ and transferred into glass petri dishes. All macrofauna specimens were determined to taxa, order or family level and subsequently frozen again at $-20^{\circ} \mathrm{C}$. To avoid contamination, different sets of sorting devices were used when processing labelled and unlabelled samples.

The isotopic ratios of macrofauna organisms were measured on an ANCA 20-20 IRMS (isotope ratio mass spectrometer, Europe Scientific). For this purpose all specimens were freeze-dried in vacuo without using any grease for sealing. Single organisms were put into tin caps and every specimen was measured separately. Prior to the IRMS measurements, the organisms were weighed on a microbalance (Sartorius) in order to achieve biomass values for each sample. The carbon isotope ratios $\left({ }^{12} \mathrm{C} /{ }^{13} \mathrm{C}\right)$ were calculated from the measured C-contents of the sample against a PDB-standard (Boutton 1991). The carbon isotope ratios are expressed in delta notation $\left(\delta^{13} \mathrm{C}\right)$ as relative difference between sample and standard: $\delta^{13} \mathrm{C}[\%$ o $]=$ $\left[\left({ }^{12} \mathrm{C} /{ }^{13} \mathrm{C}_{\text {sample }} /{ }^{12} \mathrm{C} /{ }^{13} \mathrm{C}_{\text {standard }}\right)-1\right] \times 1000$. Uptake of ${ }^{13} \mathrm{C}$ by macrofauna organisms was calculated as excess (above background) and is expressed as the specific uptake: $\Delta \delta^{13} \mathrm{C}\left(\Delta \delta^{13} \mathrm{C}=\delta^{13} \mathrm{C}_{\text {sample }}-\delta^{13} \mathrm{C}_{\text {background }}\right)$.

\section{RESULTS}

\section{Abundance, biomass and vertical distribution of macrofauna organisms}

Total macrofauna density at the abyssal BENGAL Station was $376 \pm 198$ (SD) ind. $\mathrm{m}^{-2}$. Dominant macrofauna taxa were polychaetes (52\%) and crustaceans $(44 \%)$, together comprising $96 \%$ of all macrofauna taxa (Fig. 2a). With a share of $38 \%$, the Cirratulidae were the most abundant family of Polychaeta. Other abundant families were Ophelidae (13\%), Spionidae $(12 \%)$, Nereidae (8\%) and Maldanidae (5\%) (Fig. 3a). In addition to that, 8 more families were identified at BENGAL Station, with a relative abundance between 1 and $4 \%$. Crustacean taxa consisted of 4 different orders: Tanaidacea (42\%), Isopoda (32\%), Amphipoda (21\%) and the far less abundant Cumacea (3\%).

Mean macrofauna biomass was $224 \pm 215 \mathrm{mg} d w$ $\mathrm{m}^{-2}$. In all, $55 \%$ of the total dry weight biomass were presented by Polychaeta and $44 \%$ by Crustacea (Fig. 2b), which well resembled the shares of abundance mentioned before. Biomass distribution within the polychaetes showed that 4 main families could be registered (Fig. 3b); Cirratulidae (33\%), Ophelidae $(25 \%)$, Spionidae $(24 \%)$ and Sphaerodoridae (16\%). Contrary to abundance, the greatest biomass share of Crustacea was represented by the order of Amphipoda (90\%). The remaining $10 \%$ consisted of Isopoda $(6 \%)$, Tanaidacea (3\%) and Cumacea (1\%).

\section{Vertical distribution within the sediment}

The vertical distribution of macrofauna organisms showed that $40 \%$ of all macrofauna organisms were found in the uppermost $\mathrm{cm}$ of the sediment $(0$ to $1 \mathrm{~cm})$ (Fig. 4a); the number of individuals within the surface layer was $152 \pm 89$ ind. $\mathrm{m}^{-2}$. The majority of organisms

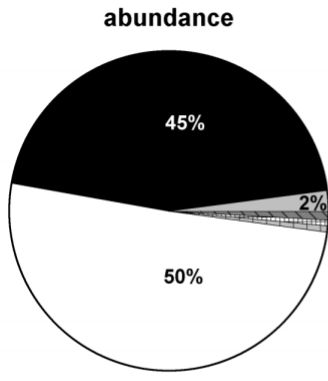

(a)
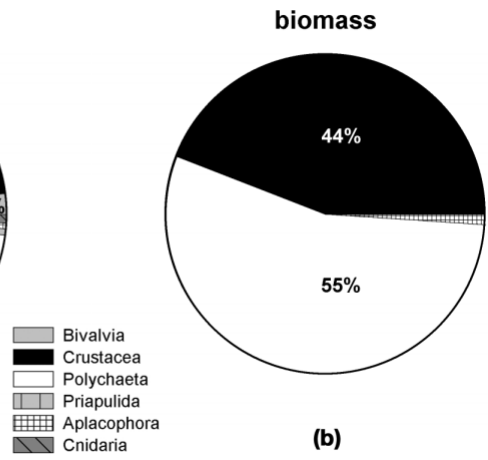

(b)
Fig. 2. (a) Relative abundance (ind. $\mathrm{m}^{-2}$ ) and (b) biomass $\left(\mathrm{mg} \mathrm{dw} \mathrm{m}^{-2}\right.$ ) of macrofauna taxa at BENGAL Station

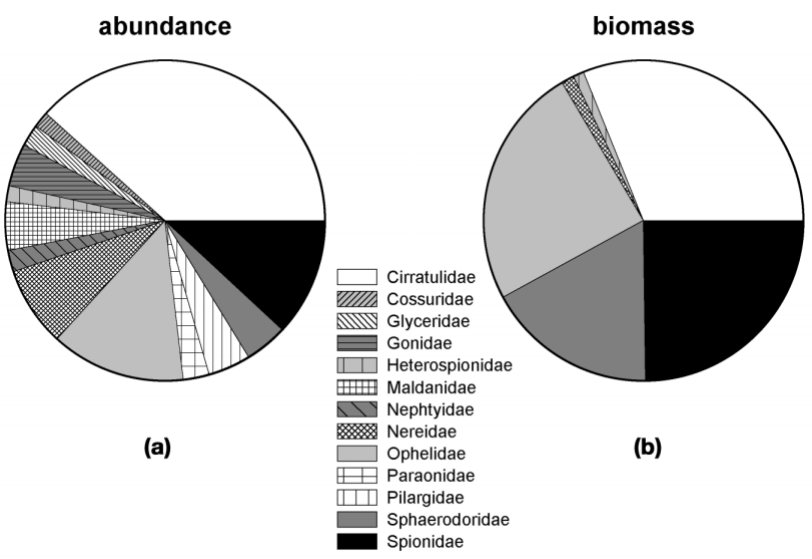

Fig. 3. (a) Relative abundance (ind. $\mathrm{m}^{-2}$ ) and (b) biomass $\left(\mathrm{mg} \mathrm{dw} \mathrm{m}^{-2}\right)$ of polychaete families at BENGAL Station 

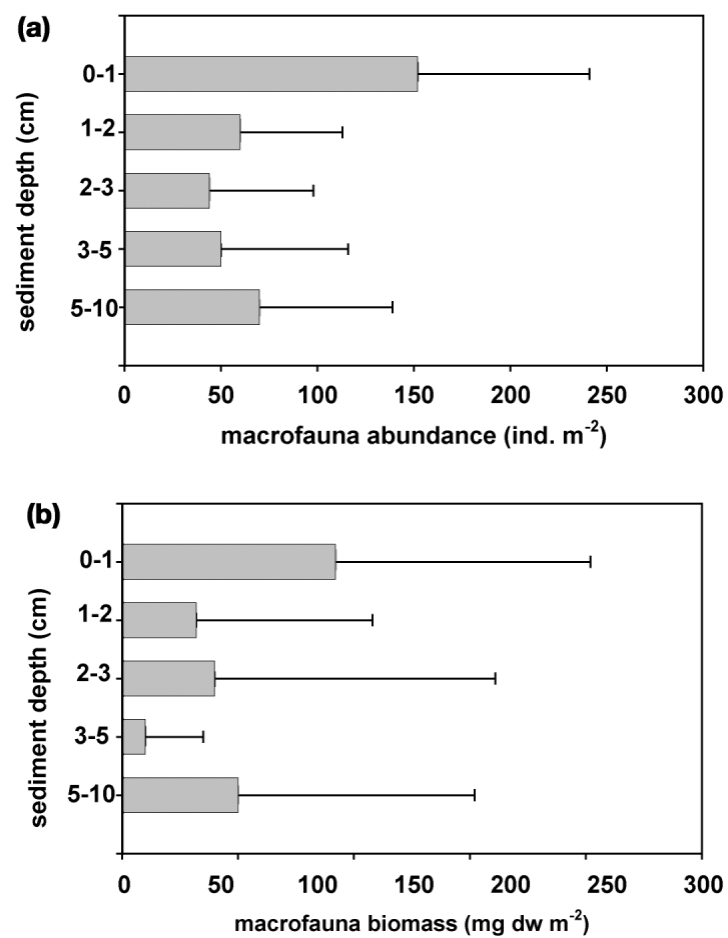

Fig. 4. Vertical distribution of (a) total macrofauna abundance and (b) biomass within the sediment column $(0$ to $10 \mathrm{~cm})$

( $80 \%$ ) lived within the upper $5 \mathrm{~cm}$ of the sediment. The number of individuals at the deeper horizons was lower than at the surface layer and ranged from $44 \pm$ 54 ind. $\mathrm{m}^{-2}(2$ to $3 \mathrm{~cm})$ to $70 \pm 69$ ind. $\mathrm{m}^{-2}$ (5 to $10 \mathrm{~cm}$ ). However, the different sediment volumes have to be taken into account. Within the sediment column below $5 \mathrm{~cm}(5$ to $10 \mathrm{~cm})$ only $19 \%$ of all macrofauna organisms were found. Vertical distribution of biomass closely resembled the vertical distribution of abundance. In all, $41 \%$ of total biomass was found in the surface layer ( 0 to $1 \mathrm{~cm}$ ), whereas only $22 \%$ was found below $5 \mathrm{~cm}$ sediment depth (5 to $10 \mathrm{~cm}$ ) (Fig. 4b). The upper $5 \mathrm{~cm}$ of the sediment column contained $78 \%$ of the total macrofauna biomass. With $92 \pm 111 \mathrm{mg} \mathrm{dw}$ $\mathrm{m}^{-2}$, biomass was highest at the sediment surface (Fig. 3b). Distribution of the most dominant taxa, Crustacea and Polychaeta, within the sediment column showed a very similar pattern. A total of $80 \%$ of all crustaceans and polychaetes were found in the upper $5 \mathrm{~cm}$ of the sediment. The number of polychaetes was quite homogeneous and ranged between 47 ind. $\mathrm{m}^{-2}$ at the surface and 58 ind. $\mathrm{m}^{-2}$ below $5 \mathrm{~cm}$. The vertical distribution of crustaceans resembled that of polychaetes, with 55 ind. $\mathrm{m}^{-2}$ at the surface and 63 ind. $\mathrm{m}^{-2}$ at the deepest sediment layer. A total of $20 \%$ of all crustaceans and polychaetes were found in the deepest sedimental horizon below $5 \mathrm{~cm}$.

\section{Isotopic signatures}

Natural isotopic signatures of macrofauna organisms from background sediments all showed negative values (Fig. 5). The mean $\delta^{13} \mathrm{C}$-signature for polychaetes was $-24.5 \pm 7.2 \%$ and for crustaceans $-23.6 \pm 7.5 \%$. Lowest natural $\delta^{13} \mathrm{C}$-signatures were measured for a polychaete belonging to the family Glyceridae $\left(\delta^{13} \mathrm{C}=\right.$ $-36.3 \%$ o and Nereidae $\left(\delta^{13} \mathrm{C}=-38.9 \%\right)$. All other polychaetes ranged between -29.4 (Maldanidae) and $-15 \%$ (Heterospionidae). Isotopic background signatures of crustaceans showed values from $-29.6 \pm 9.0 \%$ (Tanaidacea) to $-17.9 \%$ (Cumacea). Two Sipunculidae had a signature of around $-22 \%$. Natural $\delta^{13} \mathrm{C}$ signatures higher than $-15 \%$ were not observed in macrofauna from BENGAL Station. Thus, in our tracer enrichment experiments, signals greater than $-10 \%$ were considered as evidence for the uptake of ${ }^{13} \mathrm{C}$ from the introduced material.

Measurements of ${ }^{12} \mathrm{C} /{ }^{13} \mathrm{C}$-ratios from crustaceans and polychaetes within enriched sediments revealed tracer uptake during all incubation times $(2.5,8$ and $23 \mathrm{~d}$ ), as shown in Fig. $6 \mathrm{a} . \Delta \delta^{13} \mathrm{C}$-signatures of macrofauna showed that in the short-term experiments $(2.5 \mathrm{~d})$ already $76 \%$ of polychaetes and $74 \%$ of crustaceans had ingested ${ }^{13} \mathrm{C}$ from the labelled diatoms (Fig. 6b). After $8 \mathrm{~d}$ a tracer uptake was revealed for $61 \%$ of polychaetes and $85 \%$ of the crustaceans. After $23 \mathrm{~d}, 83 \%$ of polychaetes were enriched and the 2 crustaceans encountered were slightly enriched, making a $100 \%$ enrichment.

Highest $\Delta \delta^{13} \mathrm{C}$ of macrofauna taxa during all incubation times was found within the Polychaeta; however, strong variations in the degree of enrichment could be calculated for this taxon. Mean isotopic signatures ranged from $545 \pm 905 \%$ o $(2.5 \mathrm{~d}$ ) to $867 \pm 2154 \%$ o (23 d) (Fig. 6a). As far as family levels are concerned, the degree of enrichment was highest in single polychaetes from the family of Cirratulidae, where $50 \%$ of all measured polychaetes had signatures higher than

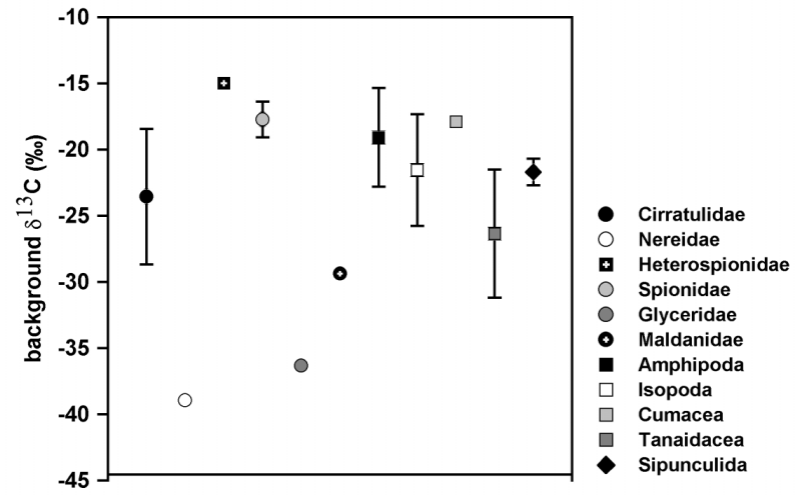

Fig. 5. Background $\delta^{13} \mathrm{C}$-signatures of macrofauna taxa at BENGAL Station 

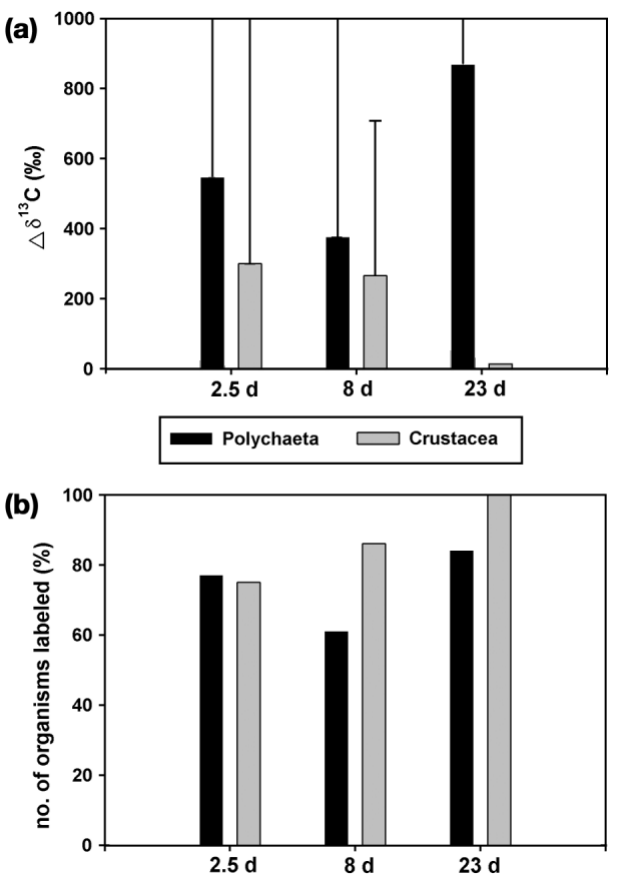

Fig. 6. (a) Mean $\delta^{13} \mathrm{C}$-signatures of combined Polychaeta and Crustacea, and (b) no. of organisms labeled (\%), within enriched sediments during 3 incubation periods $(2.5,8$ and 23 d) at BENGAL Station

$400 \%$ and where the maximum signatures of $5747 \%$ was detected after $23 \mathrm{~d}$ (Table 2). In addition to that, a single Spionidae and a Maldanidae showed values higher than $2000 \%$.

In comparison to the Polychaeta, the tracer uptake of Crustacea showed much lower signals that ranged from $299 \pm 873 \%$ after 2.5 d, $265 \pm 443 \%$ after $8 d$, to a mean of $13 \%$ from 2 single crustaceans after $23 \mathrm{~d}$. As already pointed out for the Polychaeta, the degree of enrichment revealed strong variability within this taxonomic group too. Signatures higher than 100\%o were measured for amphipods and a single isopod; a maximum signature of $2460 \%$ was detected for an amphipod after $2.5 \mathrm{~d}$ (Table 2).

\section{Vertical distribution of isotopic signatures}

In order to investigate in which way organic material is transported down into deeper sediment layers, isotopic signatures of macrofauna were studied within the sediment column. The highest mean ${ }^{13} \mathrm{C}$-tracer enrichment for crustaceans and polychaetes were detected during all incubation times at the sediment surface (Fig. 7). Macrofauna below the surface (1 to $2 \mathrm{~cm}$ ) showed slightly lower $\Delta \delta^{13} \mathrm{C}$-values, but were still clearly enriched. Penetration of tracers into deeper sediment layers (below $2 \mathrm{~cm}$ ) occurred only occasion- ally. ${ }^{13} \mathrm{C}$-penetration within the sediment column in general reached a maximum during the long-term experiment ( $23 \mathrm{~d})$.

As far as the access to fresh phytodetritus is concerned, it has been revealed within this study that $95 \%$ of all organisms measured from the sediment surface ( $\mathrm{n}=20$ ) had taken up ${ }^{13} \mathrm{C}$ from the introduced material (Table 2), whereas only $47 \%$ of the deep dwelling individuals (5 to $10 \mathrm{~cm}$ ) showed tracer uptake, and signatures were much lower than at the surface.

In addition to that, it has to be pointed out that signatures higher than $400 \%$ occurred only in individuals of the Cirratulidae, Spionidae, Maldanidae and Amphipoda that lived in the uppermost surface layers; e.g. 5 out of 7 cirratulids that were measured from the uppermost surface layer (0 to $1 \mathrm{~cm}$ ) had signatures higher than $500 \%$.

\section{DISCUSSION}

Macrofauna abundances are known to decrease exponentially with increasing water depth (Rowe et al. 1982, Flach \& Heip 1996, Cosson et al. 1997), and our macrofauna abundance data for BENGAL Station fit well within the regression line published by Flach \& Heip (1996) for the NE Atlantic and to abundance data from other abyssal regions (Sibuet et al. 1984, Richardson \& Young 1987, Sibuet et al. 1989, Witte 2000). Glover et al. (2001; mesh size $300 \mu \mathrm{m})$ detected mean polychaete densities of 342 ind. $\mathrm{m}^{-2}$ at PAP. Assuming that around $50 \%$ of the abundance is represented by polychaetes, these densities seem similar to our data. However, Galeron et al. (2001) found considerably higher macrofaunal abundances for BENGAL Station. These differences are likely to be due to methodological variations, e.g. sampled sediment volumina, sieve sizes, and preservation methods. Sample size, in particular $(20 \times 20 \mathrm{~cm}$ lander chamber vs $50 \times 50 \mathrm{~cm}$ box core), may be responsible for an underestimation of macrofaunal abundance and biomass in our study. In addition, macrofaunal abundance at BENGAL Station varies temporally due synchronous recruitment of benthic biota (Vanreusel et al. 2001). Another factor to be considered is the effect of patchiness that is well studied for deep-sea environments (Gage 1996, Cosson et al. 1997). The patchy distribution of macrofauna is favoured by biological or physical disturbances that create heterogeneity. Such effects can not be excluded as far as the comparability with other studies is concerned. But as the oxygen measurements within the chambers showed a relatively constant depletion of oxygen by benthic fauna during all incubation times, the influence of patchiness seems to be negligible as far as comparisons within the chambers are drawn. 
Table 2. Isotopic signatures of single macrofauna organisms within enriched sediments during 3 incubation periods (2.5, 8 and $23 \mathrm{~d})$ and their vertical position within the sediment column (0 to $10 \mathrm{~cm})$. indet.: undetermined

\begin{tabular}{|c|c|c|c|c|c|c|}
\hline & $\begin{array}{c}\delta^{13} \mathrm{C}(\%) \\
2.5 \mathrm{~d}\end{array}$ & $\begin{array}{c}\text { Sediment } \\
\text { depth }(\mathrm{cm})\end{array}$ & $\begin{array}{c}\delta^{13} \mathrm{C}(\%) \\
8 \mathrm{~d}\end{array}$ & $\begin{array}{l}\text { Sediment } \\
\text { depth }(\mathrm{cm})\end{array}$ & $\begin{array}{c}\delta^{13} \mathrm{C}(\%) \\
23 \mathrm{~d}\end{array}$ & $\begin{array}{l}\text { Sediment } \\
\text { depth }(\mathrm{cm})\end{array}$ \\
\hline \multicolumn{7}{|l|}{ Polychaeta } \\
\hline \multirow{7}{*}{ Cirratulidae } & 591.1 & $0-1$ & 7.0 & $0-1$ & 5746.6 & $0-1$ \\
\hline & 1329.3 & $0-1$ & 2982.7 & $0-1$ & 79.9 & $5-10$ \\
\hline & 2023.7 & $0-1$ & 420.4 & $1-2$ & -6.6 & $5-10$ \\
\hline & 20.8 & $0-1$ & -20.8 & $3-5$ & & \\
\hline & 426.5 & $1-2$ & & & & \\
\hline & -20.5 & $3-5$ & & & & \\
\hline & -16.5 & $5-10$ & & & & \\
\hline \multirow[t]{4}{*}{ Polychaeta (indet.) } & 1824.4 & $0-1$ & -7.0 & $3-5$ & -23.2 & $5-10$ \\
\hline & -26.0 & $5-10$ & 1437.7 & $3-5$ & & \\
\hline & & & -16.5 & $5-10$ & & \\
\hline & & & 17.4 & $5-10$ & & \\
\hline \multirow[t]{2}{*}{ Nereidae } & 263.6 & $0-1$ & -17.1 & $1-2$ & & \\
\hline & -9.5 & $1-2$ & & & & \\
\hline \multirow[t]{3}{*}{ Spionidae } & 2371.9 & $1-2$ & -15.7 & $5-10$ & 21.4 & $0-1$ \\
\hline & -27.1 & $2-3$ & & & 277.6 & $5-10$ \\
\hline & 42.8 & $5-10$ & & & & \\
\hline \multirow[t]{3}{*}{ Maldanidae } & 2873.8 & $0-1$ & & & & \\
\hline & 8.0 & $3-5$ & & & & \\
\hline & -18.6 & $5-10$ & & & & \\
\hline \multirow[t]{2}{*}{ Sphaerodoridae } & 26.7 & $1-2$ & -15.8 & $1-2$ & & \\
\hline & 198.2 & $1-2$ & 118.8 & $2-5$ & & \\
\hline Glyceridae & 145.5 & $0-1$ & & & & \\
\hline \multirow[t]{2}{*}{ Ophelidae } & -13.2 & $0-1$ & & & & \\
\hline & -6.3 & $5-10$ & -9.8 & $2-5$ & & \\
\hline \multicolumn{7}{|l|}{ Crustacea } \\
\hline \multirow[t]{4}{*}{ Amphipoda } & -8.4 & $2-3$ & 93.5 & $0-1$ & & \\
\hline & 2460.2 & $2-3$ & 1233.4 & $0-1$ & & \\
\hline & & & 287.4 & $0-1$ & & \\
\hline & & & -13.2 & $1-2$ & & \\
\hline \multirow[t]{2}{*}{ Isopoda } & -10.4 & $2-3$ & 244.1 & $0-1$ & & \\
\hline & & & 33.3 & $1-2$ & & \\
\hline Cumacea & -0.4 & $0-1$ & & & & \\
\hline \multirow{4}{*}{ Tanaida } & -1.1 & $2-3$ & -16.7 & $5-10$ & 25.5 & $0-1$ \\
\hline & -27.6 & $2-3$ & & & 1.9 & $5-10$ \\
\hline & 8.0 & $2-3$ & & & & \\
\hline & -24.0 & $5-10$ & & & & \\
\hline
\end{tabular}

The taxonomic composition of macrofauna showed similar patterns in former studies as compared to this study. Among the macrofauna, polychaetes are known to be the dominant group in terms of abundance and biomass (Hessler \& Jumars 1974, Cosson et al. 1997), whereas the portion of crustaceans was slightly higher in our study. When comparing biomass data from former studies with biomass values determined at BENGAL Station, difficulties arise due to the different biomass units used. In general it is claimed that at continental margins, biomass values are as high as $1 \mathrm{~g} \mathrm{C}$ $\mathrm{m}^{-2}$, and that there is a decrease in biomass with increasing water depth (Thomsen et al. 1995, Flach \& Heip 1996). In abyssal regions with limited food supply, biomass values ranging between 50 and $340 \mathrm{mg}$ ww $\mathrm{m}^{-2}$ (Sibuet et al. 1984, Richardson \& Young 1987), or 20 to $80 \mathrm{mg} \mathrm{C} \mathrm{m}^{-2}$ (Flach \& Heip 1996, Witte 2000), were observed. At BENGAL Station we encountered ca. 220 $\mathrm{mg} \mathrm{dw} \mathrm{m}^{-2}$, thus representing the upper average.

Cosson et al. (1997) revealed a linear relationship between the food supply of abyssal regions and the abundance of macrofauna. The mesotrophic conditions of the overlying water body, and as a result from that a highly food limited benthic community at the PAP (Iken et al. 2001), could be a possible explanation for the low macrofauna densities that were detected within this study.

Previous publications point out the great importance of the uppermost sediment layers for macrofauna organisms (Flach \& Heip 1996, Witte 2000); usually 40 


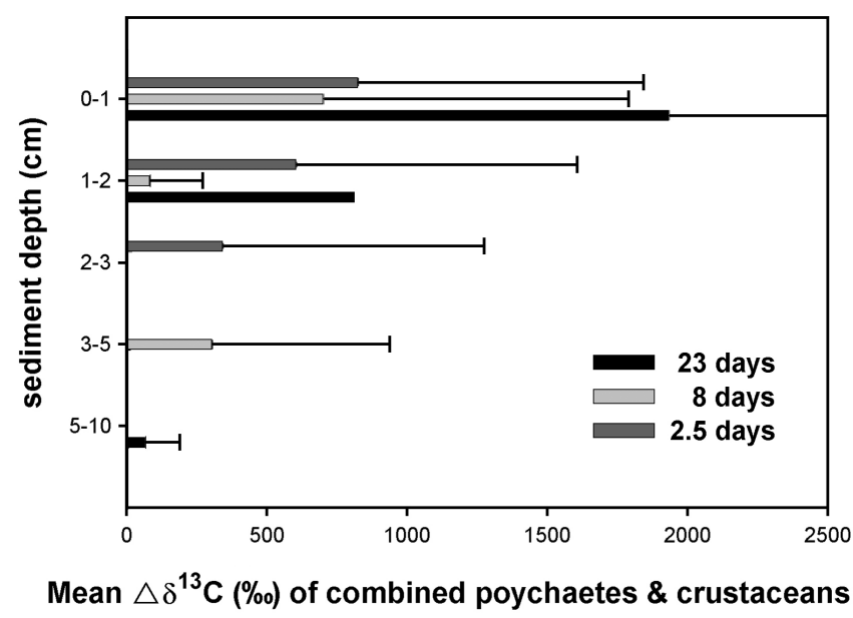

Fig. 7. Vertical distribution of mean $\delta^{13} \mathrm{C}$-signatures of Polychaeta and Crustacea within the sediment column $(0$ to $10 \mathrm{~cm})$

to $80 \%$ of all macrofauna were found within the sediment surface ( 0 to $1 \mathrm{~cm}$ ) and ca. $80 \%$ within the upper $5 \mathrm{~cm}$ of the sediment. Deeper sediment horizons showed much lower individual numbers. These investigations correspond very well to the vertical distribution at BENGAL Station; crustaceans and polychaetes, as the major macrofauna taxa, showed very similar distribution patterns, and a preference of different taxa for special sediment horizons as shown in other publications (Flach \& Heip 1996, Witte 2000) could not be detected. As far as the vertical distribution of biomass parameters is concerned, our study showed corresponding biomass and abundance values. Contrasting vertical patterns of biomass and abundance, as reported from the Arabian Sea (Witte 2000) or from the continental margin close to PAP (Flach \& Heip 1996), could not be investigated at BENGAL Station.

In recent years the use of stable isotope techniques for the investigation of trophic interactions within marine food-webs has gained a lot of interest. Natural isotopic compositions can be used for investigations on food sources, and trophic levels (Fry \& Sherr 1986, Peterson \& Fry 1987, Fry 1988) or stable isotope labelling can serve as tracers in studies on carbon flux and food-webs in marine communities. Former publications have revealed that as far as food-web analysis is concerned, ${ }^{15} \mathrm{~N}$ seems to be a more conservative, less variable and therefore more reliable tracer (DeNiro \& Epstein 1981, Fry 1988). In contrast, ${ }^{13} \mathrm{C}$ has been successfully used as a tracer for enrichment experiments, and for quantifying the uptake and incorporation of tracer carbon into body tissues (Levin et al. 1999, Herman et al. 2000, Middelburg et al. 2000). Our project focused on energy fluxes within the whole abyssal community (bacteria, meiofauna, macrofauna) with the aim of following and quantifying the food-pulse through all trophic levels of the food-web. Due to the fact that tracer-uptake by bacteria has been quantified via polar lipid fatty acid (PLFA) analysis, ${ }^{13} \mathrm{C}$ was chosen as the tracer. The natural isotopic signatures of an organism resemble the isotopic composition of its food source (Fry 1988, Blair et al 1996). On an average background, ${ }^{13} \mathrm{C}$-isotopic signatures for macrofauna organisms at BENGAL Station showed fairly low values; the mean ${ }^{13} \mathrm{C}$-signature for Polychaeta was $-25 \%$ and for Crustacea $-24 \%$. In comparison to values from the bathyal continental margin at Cape Hatteras, where polychaetes had much higher signals ranging in mean between sites from -16 to $-19 \%$ and nonannelid metazoans ca. $-18 \%$ o (Levin et al. 1999), the background signatures in our study are 6 to $9 \%$ o lower. This might indicate that a much more 'refractory' food source is available for macrofauna at PAP (4850 m) compared to the Cape Hatteras $(850 \mathrm{~m})$ study site. Polunin et al. (2001) revealed ${ }^{13} \mathrm{C}$-signatures ranging from -20 to -21 for suprabenthic crustaceans from the bathyal Mediterranean. POM from the pelagial at BENGAL Station has carbon isotope ratios of ca. $-22 \%$ (Iken et al. 2001); this strongly indicates a dependence of the benthic food-web on sedimented POM. Contrary to background signatures measured in our study, these are natural stable isotope measurements conducted by Iken et al. (2001) at PAP in September 1996 and July 1997, where polychaetes showed ${ }^{13} \mathrm{C}$-signatures ranging between -16 and $-20 \%$ and crustaceans ca. $-18 \%$. These variations in stable isotope signatures might be due to different sampling periods; in our case natural isotope signatures were measured from organisms sampled before the spring bloom had settled to the deep-sea floor, whereas the study of Iken et al. (2001) was conducted during summer and autumn 1996/97 after the setting of the spring bloom. Thus organisms in spring depending on much older food sources might have much lower isotope signals than macrofauna during summer or autumn right after a sedimentation event.

The ${ }^{13} \mathrm{C}$-isotopic signatures varied to a high degree between different taxa and even families. The reasons for these strong variations can be found in a highly selective ingestion, different degrees of assimilation or even in the specific feeding modes of different species (Hentschel 1998). From the analysis of gut contents, Cartes et al. (2001), for example, reported different food sources like detritus or living prey in the diet of peracarid crustaceans, and Polunin et al. (2001) showed that more than 1 trophic level occurred among macrofaunal groups. These facts strongly indicate that macrofauna in general can not be considered as 1 functional group and that even on taxa or family levels strong variations might occur. 
The ${ }^{13} \mathrm{C}$-signatures of the enrichment experiments showed a rapid uptake of the introduced algal material by macrofauna organisms within all incubation times. After $2.5 \mathrm{~d}$, high ${ }^{13} \mathrm{C}$-signatures could already be detected in different taxa and families, and after $23 \mathrm{~d}$ the level of enrichment culminated and the highest signatures occurred. In addition to the direct uptake of labelled phytodetritus, macrofauna may have preyed on meiofauna organisms (Svavarson et al. 1993), which also showed a very rapid ingestion of the carbon label within the same experiments (S. Sommer pers. comm.). In our study, isotope signatures were determined for whole organisms, thus the uptake of material into the animals gut system and the incorporation of material into body tissue cannot be discriminated between. However, during the long-term experiment it is likely that the relative amount of labelled carbon incorporated into the body tissue is increasing.

When comparing the 2 dominant taxa of this study, Polychaeta and Crustacea, it becomes obvious that crustaceans played a minor role in reworking the introduced material, although their abundance and biomass was only slightly lower compared to polychaetes. The role of surface deposit-feeding polychaetes, e.g. Cirratulidae and Spionidae (Fauchald \& Jumars 1979), should be emphasized particularly in this context, since these families showed the most rapid uptake, and overall the highest ${ }^{13} \mathrm{C}$-signatures of all macrofauna organisms. The assumption that strong competition for food in the abyssal benthic food-web is present, and therefore development of different feeding strategies takes place, seems to be confirmed in this study. Highly specialized surface deposit-feeding organisms seem to out-compete other feeding specialists, e.g. predators, suspension feeders and subsurface depositfeeders.

The vertical distribution of ${ }^{13} \mathrm{C}$-signatures showed highest enrichment in macrofauna organisms living in the upper sediment column $(0$ to $5 \mathrm{~cm})$. Highest ${ }^{13} \mathrm{C}$-signals in these sedimental horizons were detected after $23 \mathrm{~d}$ but reached already considerably high values after both 2.5 and $8 \mathrm{~d}$. Below $5 \mathrm{~cm}$, only slight enrichment could be detected, which was only evident during single incubation experiments. The assumption that macrofauna living close to the sediment surface had the highest access to freshly deposited material was thus confirmed. On the contrary, Jumars et al. (1990) claimed that when food is scarce it is advantageous to store as much food, as fast as possible, out of the reach of competitors, and therefore most organisms in these highly food-limited abyssal regions are found beneath the sediment surface. Jumars' hypothesis was strengthened by pulse-chase experiments conducted by Levin et al. (1999) at the North Carolina continental slope $(850 \mathrm{~m})$ and in the bathyal region of the Norwe- gian Sognefjord at $1265 \mathrm{~m}$ depth (Witte et al. 2003). Both studies reported a similarly rapid downward mixing of labile organic matter down to $10-15 \mathrm{~cm}$, and revealed the great importance of deep-dwelling macrofauna organisms.

These results differ from our experiments and a possible explanation could be the low abundance of deep dwelling polychaete families, e.g. maldanidae and ophelidae, whose burrowing lifestyles are well known (Fauchald \& Jumars 1979, Levin et al. 1999). In contrast, the family of Cirratulidae was especially abundant at the surface of our enriched sediments, and showed the highest ${ }^{13} \mathrm{C}$-signals. Cirratulids are thought to be surface deposit-feeders, sessile or mobile without showing any burrowing activity (Fauchald \& Jumars 1979). Due to the high tracer uptake detected for cirratulids in our experiment, the Cirratulidae might have a key function in reworking freshly deposited material at the PAP. Our results indicate that the rapid subduction of material might be a characteristic feature for continental slope rather than abyssal sediments.

Acknowledgements. We would like to thank the captain and crew of RV 'Poseidon' for their great support at sea, and Axel Cremer and Wolfgang Queisser for technical assistance with the lander systems. Peter Lamont and Bhavani E. Narayanaswamy from the Dunstaffnage Marine Laboratory/Oban provided kind and invaluable support in introducing us to deepsea polychaete taxonomy, and we thank them greatly. We shared algal cultivation and sieving of the samples, as well as many valuable discussions, with Stefan Sommer (GEOMAR). Olaf Pfannkuche is thanked for the splendid coordination of the BIGSET programme. This work was funded by the 'Bundesministerium für Bildung und Forschung' as part of the BIGSET programme (Förderzeichen 03F0273A/1).

\section{LITERATURE CITED}

Barnett PRO, Watson J, Connelly D (1984) A multiple corer for taking virtually undisturbed samples from shelf bathyal and abyssal sediments. Oceanol Acta 7:399-408

Billett DSM, Rice AL (2001) The BENGAL programme: introduction and overview. Prog Oceanogr 50:13-25

Billett DSM, Lampitt RS, Rice AL, Mantoura RFC (1983) Seasonal sedimentation of phytoplankton to the deep sea benthos. Nature 302:520-522

Blair NE, Levin LA, Demaster DJ, Plaia G (1996) The shortterm fate of fresh algal carbon in continental slope sediments. Limnol Oceanogr 41:1208-1219

Boutton TW (1991) Stable carbon isotope ratios of natural materials: I. Sample preparation and mass spectrometric analysis. In: Coleman DC, Fry B (eds) Carbon isotope techniques, Vol I. DC Coleman, San Diego, p 155-177

Cartes JE, Elizalde M, Sorbe JC (2001) Contrasting lifehistories, secondary production, and trophic structure of peracarid assemblages of the bathyal suprabenthos from the Bay of Biscay (NE Atlantic) and the Catalan Sea (NW Mediterranean). Deep-Sea Res I 48:2209-2232

Cosson N, Sibuet M, Galeron J (1997) Community structure and spatial heterogeneity of the deep-sea macrofauna at 
three contrasting stations in the tropical northeast Atlantic. Deep-Sea Res I 44:247-269

DeNiro MJ, Epstein S (1981) Influence of diet on the distribution of nitrogen isotopes in animals. Geochem $\mathrm{J} 45$ : 341-352

Deuser WG, Ross EH, Anderson RF (1981) Seasonality in the supply of sediment to the deep Sargasso Sea Atlantic Ocean and implications for the rapid transfer of matter to the deep ocean. Deep-Sea Res I 28:495-506

Fauchald K, Jumars P (1979) The diet of worms: a study of polychaete feeding guilds. Oceanogr Mar Biol Annu Rev $17: 193-284$

Flach E, Heip C (1996) Vertical distribution of macrozoobenthos within the sediment on the continental slope of the Goban Spur area (NE Atlantic). Mar Ecol Prog Ser 141: $55-66$

Fry B (1988) Food-web structure on Georges Bank (Northwestern Atlantic Ocean) from stable carbon nitrogen and sulphur isotopic compositions. Limnol Oceanogr 33: $1182-1190$

Fry B, Sherr EB (1986) Delta carbon-13 measurements as indicators of carbon flow in marine and freshwater ecosystems. In: Rundel PW, Ehleringer JR, Nagy KA (eds) Stable isotopes in ecological research. Springer-Verlag, New York

Gage JD (1996) Why are there so many species in deep-sea sediments? J Exp Mar Biol Ecol 200:257-286

Gage JD, Tyler P (1991) Deep sea biology: a natural history of organisms at the deep sea floor. Cambridge University Press, Cambridge

Galeron J, Sibuet M, Vanreusel A, Mackenzie K, Gooday AJ, Dinet A, Wolff G (2001) Temporal patterns among meiofauna and macrofauna taxa related to changes in sediment geochemistry at an abyssal NE Atlantic site. Prog Oceanogr 50:303-324

Glover A, Paterson G, Bett B, Gage J, Sibuet M, Sheader M, Hawkins L (2001) Patterns in polychaete abundance and diversity from the Madeira Abyssal Plain, Northeast Atlantic. Deep-Sea Res I 48:217-236

Gooday AJ (1986) Meiofaunal foraminiferans from the bathyal Porcupine Seabight Northeast Atlantic size structure standing stock taxonomic composition species diversity and vertical distribution in the sediment. Deep-Sea Res I 33:1345-1374

Gooday AJ (1988) A response by Benthic foraminifera to the deposition of phytodetritus in the deep sea. Nature 332: 70-73

Gooday AJ (1996) Epifaunal and shallow infaunal foraminiferal communities at three abyssal NE Atlantic sites subject to differing phytodetritus input regimes. Deep-Sea Res I 43:1395-1421

Gooday AJ, Turley CM (1990) Response by benthic organisms to input of organic material to the ocean floor. Phil Trans R Soc Lond 331:119-138

Gooday AJ, Bett BJ, Pratt DN (1993) Direct observation of episodic growth in an abyssal xenophyophore (Protista). Deep-Sea Res I 40:2131-2143

Graf G (1989) Benthic-pelagic coupling in a deep-sea benthic community. Nature 341:437-439

Guillard R, Ryther JH (1962) Studies of marine planctonic diatoms. Can J Microbiol 8:229-239

Hentschel BT (1998) Intraspecific variations in $\Delta^{13} \mathrm{C}$ indicate ontogenetic diet changes in deposit-feeding polychaetes. Ecology 79:1357-1370

Herman PMJ, Middelburg JJ, Widdows J, Lucas CH, Heip CHR (2000) Stable isotopes as trophic tracers: combining field sampling and manipulative labelling of food resources for macrobenthos. Mar Ecol Prog Ser 204:79-92
Hessler RR, Jumars PA (1974) Abyssal community analysis from replicate box cores in the Central North Pacific. Deep-Sea Res 21:185-209

Honjo S (1982) Seasonality and interaction of biogenic and lithogenic particulate flux at the Panama Basin. Science 218:883-884

Honjo S, Manganini SJ (1993) Annual biogenic particle fluxes to the interior of the North Atlantic Ocean: studied at 34 degrees N, 21 degrees $\mathrm{W}$ and 48 degrees N, 21 degrees W. Deep-Sea Res II 40:587-607

Iken K, Brey T, Wand U, Voigt J, Junghans P (2001) Food-web structure of the benthic community at the Porcupine Abyssal Plain (NE Atlantic): a stable isotope analysis. Prog Oceanogr 50:383-405

Jumars PA, Mayer LM, Deming JW, Baross JA, Wheatcroft RA (1990) Deep-sea deposit-feeding strategies suggested by environmental and feeding constraints. Phil Trans R Soc Lond 331:85-101

Lampitt RS (1985) Evidence for the seasonal deposition of detritus to the deep-sea floor and its subsequent resuspension. Deep-Sea Res 32:885-897

Levin LA, Blair NE, DeMaster DJ, Plaia G, Fornes W, Martin CM, Thomas CJ (1997) Rapid subduction of organic matter by maldanid polychaetes on the North Carolina slope. J Mar Res 55:595-611

Levin LA, Blair NE, Martin CM, DeMaster DJ, Plaia G, Thomas CJ (1999) Macrofaunal processing of phytodetritus at two sites on the Carolina margin: in situ experiments using ${ }^{13}$ C-labelled diatoms. Mar Ecol Prog Ser 182:37-54

Linke P, Altenbach AV, Graf G, Heeger T (1995) Response of deep-sea benthic foraminifera to a simulated sedimentation event. J Foraminifer Res 25:75-82

Lochte K, Turley CM (1988) Bacteria and cyanobacteria associated with phytodetritus in the deep sea. Nature 333: 67-69

Lohrenz SE, Knauer GA, Asper VL, Tuel M, Michaels AF, Knap AH (1992) Seasonal variability in primary production and particle flux in the Northwestern Sargasso Sea JGOFS Bermuda Atlantic Time-Series Study. Deep-Sea Res I 39:1373-1391

Middelburg JJ, Barranguet C, Boschker HTS, Herman PMJ, Moens T, Heip CHR (2000) The fate of intertidal microphytobenthos carbon: an in situ ${ }^{13} \mathrm{C}$-labeling study. Limnol Oceanogr 45:1224-1234

Newton PP, Lampitt RS, Jickells TD, King P, Boutle C (1994) Temporal and spatial variability of biogenic particle fluxes during the JGOFS northeast Atlantic process studies at $47^{\circ} \mathrm{N}, 20^{\circ} \mathrm{W}$. Deep-Sea Res I 41:1617-1642

Nowell ARM, Jumars PA, Fauchald K (1984) The foraging strategy of a subtidal and deep sea deposit-feeder. Limnol Oceanogr 29:645-649

Peterson BJ, Fry B (1987) Stable isotopes in ecosystem studies. Annu Rev Ecol Syst 18:293-320

Pfannkuche O (1993) Benthic response to the sedimentation of particulate organic matter at the BIOTRANS station, 47 degrees N, 20 degrees W. Deep-Sea Res II 40:135-149

Pfannkuche O, Utecht C (2001) Cruise Report Pos 260. In: Pfannkuche O (ed) BIGSET (Biogeochemical transport of matter and energy in the deep sea). GEOMAR Report 100, GEOMAR, Kiel

Polunin NVC, Morales-Nin B, Pawsey WE, Cartes JE, Pinnegar JK, Moranta J (2001) Feeding relationships in Mediterranean bathyal assemblages elucidated by stable nitrogen and carbon isotope data. Mar Ecol Prog Ser 27: $13-23$

Rice AL, Billett DSM, Fry J, John AWG, Lampitt RS, Mantoura RFC, Morris RJ (1986) Seasonal deposition of phyto- 
detritus to the deep-sea floor. Proc R Soc Ed B (Biol Sci): $265-280$

Rice AL, Billett DSM, Thurston MH, Lampitt RS (1991) The Institute of Oceanographic Sciences Biology Program in the Porcupine Sea bight background and general introduction. J Mar Biol Assoc UK 71:281-310

Rice AL, Thurston MH, Bett BJ (1994) The IOSDL DEEPSEAS programme: introduction and photographic evidence for the presence and absence of a seasonal input of phytodetritus at contrasting abyssal sites in the northeast Atlantic. Deep-Sea Res I 41:1305-1320

Richardson MD, Young DK (1987) Abyssal benthos of the Venezuela Basin Caribbean Sea standing stock considerations. Deep-Sea Res I 34:145-164

Rowe GT, Polloni PT, Haedrich RL (1982) The deep sea macrobenthos on the continental margin of the Northwest Atlantic Ocean. Deep-Sea Res I 29:257-278

Sibuet M, Lambert CE, Chesselet R, Laubier L (1989) Density of the major size groups of benthic fauna and trophic input in deep basins at the Atlantic Ocean. J Mar Res 47: 851-867

Sibuet M, Monnito C, Desbruyeres D, Dinet A, Khripounoff A, Rowe G, Segonzac M (1984) Benthic populations and trophic characteristics in the Demerara Abyssal Basin, Atlantic Ocean. Oceanol Acta 7:345-358

Svavarsson J, Gudmundsson G, Brattegard T (1993) Feeding by asellote isopods (Crustacea) on foraminifers (Protozoa) in the deep sea. Deep-Sea Res I 40:1225-1239

Editorial responsibility: Otto Kinne (Editor),

Oldendorf/Luhe, Germany
Thiel H, Pfannkuche O, Schriever G, Lochte K and 6 others (1989) Phytodetritus on the deep-sea floor in a central oceanic region of the Northeast Atlantic. Biol Oceanogr 6: 203-239

Thomsen L, Graf G, von Juterzenka K, Witte U (1995) An in situ experiment to investigate the depletion of seston above an interface feeder field on the continental slope on the western Barents Sea. Mar Ecol Prog Ser 123:295-300

Tyler PA, Billett DSM, Gage JD (1990) Seasonal reproduction in the sea star Dytaster grandis from $4000 \mathrm{M}$ in the Northeast Atlantic Ocean. J Mar Biol Assoc UK 70:173-180

Vanreusel A, Cosson-Sarradin N, Gooday AJ, Paterson GLJ, Galeron J, Sibuet M, Vincx M (2001) Evidence for episodic recruitment in a small opheliid polychaete species from the abyssal NE Atlantic. Prog Oceanogr 50:285-301

Witte U (1996) Seasonal reproduction in deep-sea sponges. Triggered by vertical particle flux? Mar Biol 124:571-581

Witte U (2000) Vertical distribution of metazoan macrofauna within the sediment at four sites with contrasting food supply in the deep Arabian Sea. Deep-Sea Res II 47: 2979-2997

Witte U, Pfannkuche O (2000) High rates of benthic carbon remineralisation in the abyssal Arabian Sea. Deep-Sea Res II 47:2785-2804

Witte U, Aberle N, Sand M, Wenzhöfer F (2003) Rapid response of a deep-sea benthic community to POM enrichment: an in situ experimental study. Mar Ecol Prog Ser 251:27-36 (this issue)

Submitted: August 19, 2002; Accepted: December 10, 2002 Proofs received from author(s): March 13, 2003 